This item was submitted to Loughborough's Research Repository by the author.

Items in Figshare are protected by copyright, with all rights reserved, unless otherwise indicated.

\title{
Effective financial reporting and auditing: importance and limitations
}

\section{PLEASE CITE THE PUBLISHED VERSION}

http://www.qfinance.com/auditing-best-practice/effective-financial-reporting-and-auditing-importance-andlimitations?full

\section{PUBLISHER}

(c) Bloomsbury Publishing and Qatar Financial Centre Authority

\section{VERSION}

VoR (Version of Record)

\section{LICENCE}

CC BY-NC-ND 4.0

\section{REPOSITORY RECORD}

Higson, Andrew W.. 2019. "Effective Financial Reporting and Auditing: Importance and Limitations". figshare. https://hdl.handle.net/2134/10105. 
This item was submitted to Loughborough's Institutional Repository (https://dspace.lboro.ac.uk/) by the author and is made available under the following Creative Commons Licence conditions.

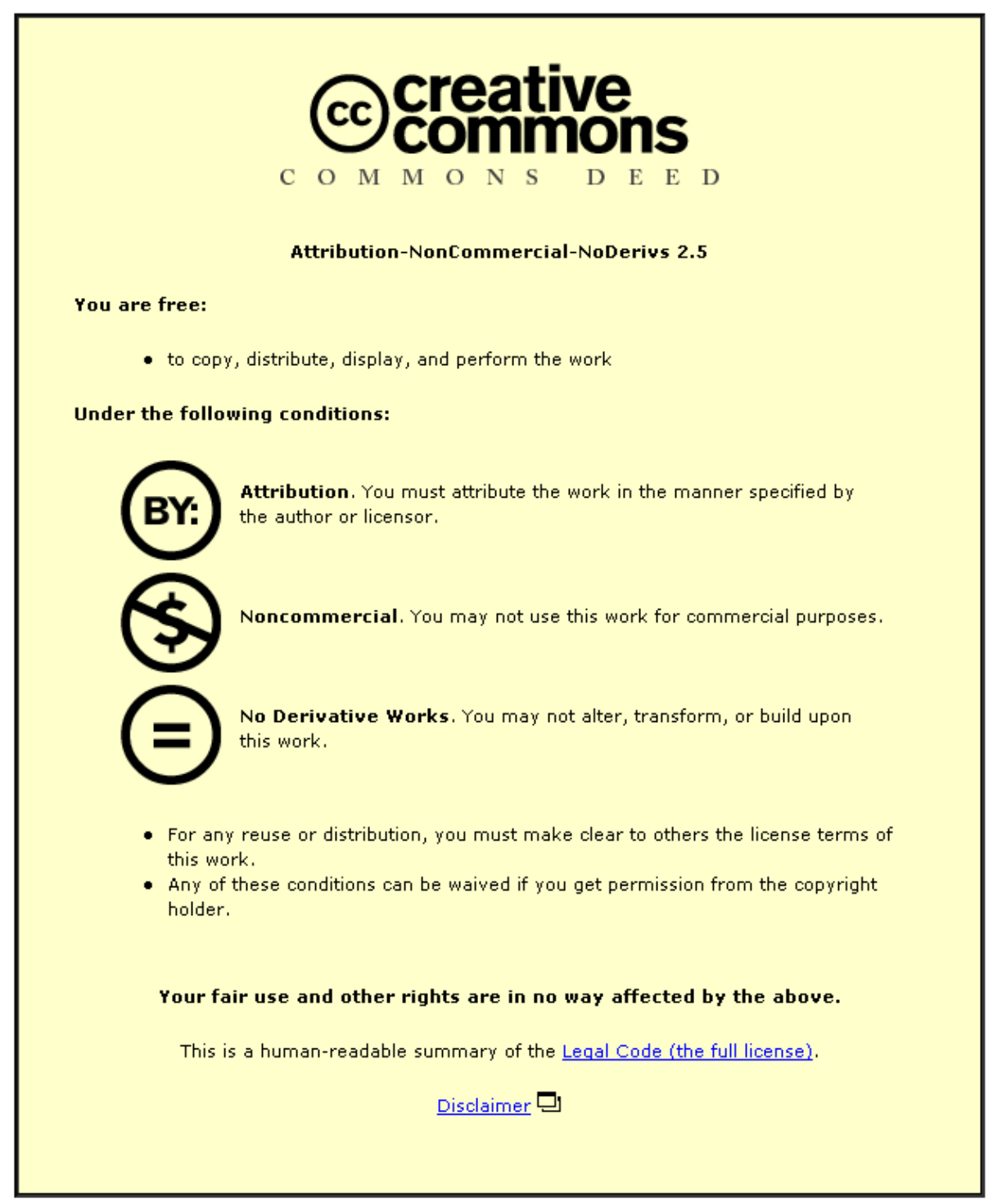

For the full text of this licence, please go to: http://creativecommons.org/licenses/by-nc-nd/2.5/ 


\section{Effective Financial Reporting and Auditing: Importance and Limitations}

by Andrew Higson

\section{Executive Summary}

- There is a debate about the specification of the objective of financial statements.

- Clear specification of this objective is important for the financial reporting standard-setters (so they can produce consistent and coherent standards), users (so they understand the nature and scope of financial reporting), external auditors (so they can say whether the financial statements are "fit for purpose"), and educationalists (so they can teach the next generation).

- The lack of clarity about the objective of the financial statements appears to have created a financial reporting expectations gap.

- Perceived defects in financial statements have resulted in a call for real-time financial reporting, but this may have the effect of creating more volatility in share price movements.

\section{Introduction}

The major problem with financial reporting is that people with limited financial knowledge can look at a set of accounts and, by attempting to interpret the numbers, feel that they understand what is happening in an organization. While in simpler times this may have been true, the scale and complexity of modern business, together with the limitations of what can be portrayed in financial statements, means that today's statements may have the capability to mislead as much as they can inform their users.

A large telecom business may have over two hundred million transactions a day in its accounting records, and such a scale of activity is almost beyond human comprehension. The complexity, and uncertainty, surrounding some transactions and financial instruments make their inclusion in the financial statements problematic to say the least. In the past accounting was defined as "an art of recording, classifying and summarizing in a significant manner and in terms of money, transactions and events which are, in part at least, of a financial character, and interpreting the results thereof."1 The need for financial reporting came about with the development of permanently invested capital (today's share capital), which required a return to be made to the shareholders for their investment over a period of time (usually annually). The separation of ownership and management, especially in larger organizations, gave rise to the need for the accountability of the managers (agents) to the owners (principals), the financial statements being a convenient basis for this. In some jurisdictions financial statements also form a basis for the calculation of taxation. This subdivision of an organization's life into artificial accounting periods may not sound exciting, but it is important. It may not cover all aspects of an organization's activities, but originally this was never intended.

\section{Decision-Usefulness}

Since the 1960s, the function of accounting has been increasingly regarded as "to provide quantitative information primarily financial in nature about economic entities that is intended to be useful in making economic decisions, in making resolved choices among alternative courses of action," ${ }^{2}$ and accounting was seen as a service activity.

On a simplistic level, the decision-usefulness approach may be intuitively appealing, but it could also be conceptually flawed and an example of circular reasoning: just because some people may take decisions based on the financial statements, does this mean that decision-usefulness should be specified as the objective of financial statements? When one takes a decision, one should be looking to the future-yet the financial statements say very little about an organization's future. One should also consider the future economic climate, an organization's competitors, and expected technological developments; financial statements say very little about these things. Often short-term investors are more concerned about taking 
their decision in anticipation (buy long, sell short) of the publication of the financial statements rather than waiting for them to come out, reading them, and then taking a decision.

An important component in the debate about the objective of financial statements has been the vagueness of the nature, scope and purpose of accounting "theory." One would have expected developments in financial reporting to have been built on theory and thus be conceptually robust. The focus on unspecified users taking unspecified decisions, at unspecified times, with unspecified results hardly seems an appropriate basis for the production of consistent and coherent financial reporting standards, and consequently there is a danger that the financial reporting standard-setters have been building on shifting sands rather than on firm foundations.

\section{The Call for Real-Time Reporting}

Given the prevailing emphasis on decision-usefulness, and the perceived limitations of financial statements in this respect, some analysts and other external parties have been calling for companies to make real-time accounting data available to them. The argument is that immediate access to, and a greater quantity of, data about a company should improve users' decision-making ability and thus improve market efficiency. However, if companies were to adopt real-time reporting (this presumably would be the reporting of results on a minute-by-minute basis rather than just putting the annual accounts on the internet), would the results make sense?

There is a danger that there has been a confusion over the "recording" aspect of accounting and the "reporting" aspect of the financial statements. "Raw" accounting data are simply a means of recording in order to keep track of the transactions undertaken by an organization-which is obviously very important for management to do. The periodic financial statements use these accounting data, and related assumptions and conventions, to allocate profit to the appropriate accounting period and to present the financial figures at a point in time (this is after the necessary cut-off adjustments and checks have been made). Given the scale of modern business, one wonders what users would really make of all the data.

To allow outsiders access to real-time "raw" accounting data does raise the question as to how exactly it would lead to greater market efficiency. Indeed, instantaneous access to real-time accounting data may not necessarily result in greater market efficiency -though greater volatility in share price movements would be a distinctly possible consequence.

\section{The Financial Reporting Expectations Gap}

It is likely there is a financial reporting expectations gap ${ }^{3}$ composed of two elements, one being an expectations gap relating to the financial statements, and the other being the audit expectations gap (Figure 1). There has been much discussion of the audit expectations gap (some users of financial statements think that the external auditors are there to detect fraud, that they produce the financial statements, that they check everything recorded by the client's accounting, etc.). The audit expectations gap has been a driving force behind the expansion of the audit report and has focused the debate about the responsibilities of the external auditors. Compared to the discussion about the audit expectations gap, the possibility of a financial statements expectations gap has almost been ignored.

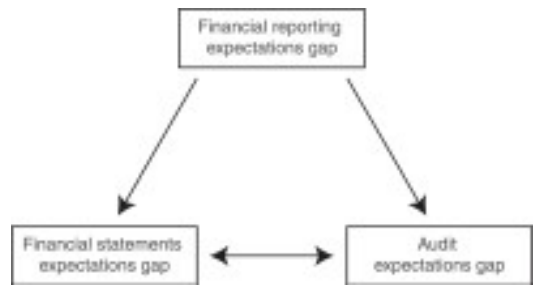

Figure 1. The financial reporting expectations gap. (Source: Higson, 2003, p. 13)

It is suggested that one element is the already discussed focus of the accountancy profession on the decision-usefulness of financial statements. Just because some people do take decisions based on them, it does not mean that they take the right decision. Another problem is the use of financial statements as 
an assessment of "performance"; this is because the financial statements per se say nothing about the economy, efficiency, and effectiveness of the organizations that produce them. There is also the tension between the long-term development of an organization and the short-term results contained in the financial statements. It is easier for users of financial statements to focus on the short-term figures contained in such statements than to try to look long-term. The broadening of the notion of performance could mean that financial statements would then be recognized for what they are-an attempt to allocate profit to the appropriate accounting period and to indicate the financial position at a point in time-and that they would then enable the debate about what constitutes corporate performance to really begin.

\section{Implications for the External Auditors}

One might assume that the audit report would be saying that the financial statements are "fit for purpose"; however, traditionally the auditors have said nothing about the decision-usefulness of financial statements. Indeed, the Company Law Review Steering Group report ${ }^{4}$ stated: "auditors have no liability to existing shareholders who rely on their report for investment decisions (for example to buy or sell shares), or actual creditors of the company who may make similar decisions about maintaining or withdrawing credit, or potential investors whether of equity or debt, or other potential creditors (for example trade creditors), who rely on the audit report for a view of the financial position of the company." It is therefore not surprising that in the United Kingdom, following the Bannerman case ${ }^{5}$ in 2003, the auditors added a paragraph to their audit report which included the advice that: "Our work has been undertaken so that we might state to the company's members those matters we are required to state to them in an auditor's report and for no other purpose ... we do not accept or assume responsibility to anyone other than the company and the company's members as a body, for our audit work, for this report, or for the opinions we have formed."

The auditors say nothing about corporate economy, efficiency, and effectiveness in their audit report. The users have to try to make their own assessment of these things based on the limited amount of data in the financial statements available to them.

It can be seen that the auditors tend to think of themselves as doing what is required of them (i.e. to follow the auditing standards and ensure that the financial statements have been produced by management in accordance with financial reporting standards), but I wonder how many readers of financial statements will understand this and understand what all these standards mean.

\section{Conclusion}

The challenges of corporate reporting in the twenty-first century can only be met once there is a real understanding about the nature, scope, and limitations of the financial statements and of the role of the external auditors.

Without a strong theoretical basis, the danger is that the financial reporting standard-setters will merely end up pandering to the perceived needs of the supposed users of financial statements.

The word "performance," in a theatrical sense, could be defined as "an act of make-believe aimed at enchanting an audience." The existence of the financial statements expectations gap may mean that this fate has already befallen the phrase "financial performance" (think about Enron's and WorldCom's financial statements!); it is important that it does not befall the phrase "corporate performance."

\section{Making It Happen}

\section{An Agenda for Developments in Corporate Reporting}

- Give consideration to a tighter and arguably more realistic specification of the objective of the financial statements.

- Increase education about the scope and limitations of financial statements and the external audit.

- Conduct a proper debate about the nature of communicating corporate performance and the assessment of corporate economy, efficiency, and effectiveness. 
- Reflect on the usefulness of real-time access to corporate accounting data.

\section{More Info}

Books:

- Deegan, C., and J. Unerman. Financial Accounting Theory. European ed. London: McGraw-Hill, 2006.

- Elliott, B., and J. Elliott. Financial Accounting and Reporting. 12th ed. Harlow, UK: FT Prentice Hall, 2007.

- Harrison Jr, W. T., and C. T. Horngren. Financial Accounting. 6th ed. Upper Saddle River, NJ: Pearson, 2005.

- Higson, A. Corporate Financial Reporting: Theory \& Practice. London: Sage Publications, 2003.

- Riahi-Belkaoui, A. Accounting Theory. 5th ed. London: Thomson, 2004.

Website:

- Corporate Financial Reporting, the author's website: www.accounting-research.org.uk

\section{Notes}

${ }^{1}$ American Institute of Accountants (AIA), Committee on Terminology (1953). Accounting Terminology Bulletin No. 1. New York: AIA, 1953, p. 9.

${ }^{2}$ Accounting Principles Board (APB). Statement No. 4: Basic Concepts and Accounting Principles Underlying Financial Statements of Business Enterprises. New York: AICPA, 1970, para. 40.

${ }^{3}$ Higson, 2003.

${ }^{4}$ Company Law Review Steering Group. Modern Company Law for a Competitive Economy: Final Report. London: DTI, 2001, para. 8.127.

${ }^{5}$ Auditing Practices Board Discussion Paper. The auditor's report: A time for change? London: Financial Reporting Council, 2007, pp. 11-12.

\section{See Also}

\section{Best Practice}

- Contemporary Developments in International Auditing Regulation

- The Effect of SOX on Internal Control, Risk Management, and Corporate Governance Best Practice

- Has Financial Reporting Impacted on Internal Auditing Negatively?

- Understanding the Requirements for Preparing IFRS Financial Statements

Checklists

- International Financial Reporting Standards (IFRS): The Basics

- Key Accounting Standards and Organizations

- The Ten Accounting Principles

Finance Library

\section{- Financial Accounting and Reporting}

To see this article on-line, please visit

http://www.qfinance.com/auditing-best-practice/effective-financial-reporting-and-auditing-importance-and-limitations?full 